\section{I \\ Seience Journal of University of Zakho}

JÜZ

Vol. 7, No. 4, pp. 132-137, December.-2019

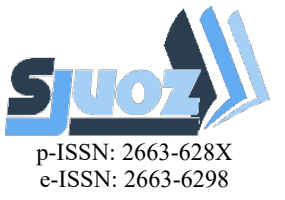

e-ISSN: 2663-6298

journals.uoz.edu.krd

\title{
PHENOTYPIC AND MOLECULAR DETECTION OF ACINETOBACTER BAUMANNII ISOLATED FROM PATIENTS IN DUHOK CITY-IRAQ
}

\author{
Zainab H. Abdullah a , Narmin S. Merza ${ }^{\text {b* }}$ \\ ${ }^{a}$ Scientific Research Center, College of Science, University of Duhok, Kurdistan Region, Iraq (zinabhassan59@yahoo.com) \\ ${ }^{\mathrm{b}}$ Dept. of Biology, College of Science, University of Duhok, Kurdistan Region, Iraq (narmin.merza@uod.ac)
}

Received: Sep., 2019 / Accepted: Nov., 2019 / Published: Dec.,2019

https://doi.org/10.25271/sjuoz.2019.7.4.644

\begin{abstract}
:
Acinetobacter baumannii (A. baumannii) is an opportunistic pathogen and one of the most importnat Multidrug resistant microorganisms responsible for a vast array of nosocomial infections. $41(6.8 \%)$ isolates of A. baumannii were obtained from a total of 603 clinical samples of burn and sputum during the period from March 2018 to February 2019. Twenty two isolates (3.6\%) of $A$. baummanni were recovered from burn infections and nineteen isolates (3.2\%) from sputum specimens. Identification and characterization of these isolates was accomplished by the aid of selective media (CHROM agar Acinetobacter) and was finally confirmed by VITEK 2 identification system test. Molecular identification utilizing genus and species-specific primers to detect the 16S rRNA and bla $a_{\mathrm{OXA}-51}$ was also applied. The Antibiotic resistance testing was done by the Kirby-Bauer disc diffusion method, $24.4 \%$ of the isolates were Multi-Drug Resistance (MDR), while $65.9 \%$ were extensive drug resistance (XDR). All isolates were absolutely resistant $(100 \%)$ to most of the antibiotics in use: cefixime, cefotaxime, ceftriaxone, ceftazidime, piperacillintazobactam, amoxicillin-tazobactam, while the resistant profile for the other antibiotics can be represented as follows $98 \%, 95 \%$, $90 \%$, and $83 \%$ For both ciprofloxacin and norfloxacin, gentamycin and meropenem, amikacin, and azithromycin and imipenem, respectively. On the other hand, levofloxacin has a moderate effect on the isolates shown by $51 \%$ resistant isolates followed by doxycycline for which $39 \%$ of the isolates were resistant. Colistin was the only antimicrobial agent that has an intense effect as the majority of the isolates were sensitive. All the selected isolates of $A$. baumannii were successfuly produced band corresponded to the intended genes. Accurate and early detection of such bacteria is essential for stimulates effective treatment specifically in intensive care units. Molecular techniques have been successfully applied with high specificity using 16S rRNA and blaOXA-51like gene as a simple and reliable method to differentiate $A$. baumannii strains.
\end{abstract}

KEYWORDS: Acinetobacter Baumannii, Blaoxa-51, Polymerase Chain Reaction, 16s Rrna.

\section{INTRODUCTION}

Acinetobacter baumannii is one of the most important pathogens responsible for hospital-acquired infections, particularly in intensive care units (ICUs) (Banerjee et al.,2018) . This bacterium can be easily isolated from water, soil, and health care environments (Ecker et al., 2006). A. baumannii as a nosocomial opportunistic pathogen is resistant to a wide range of antibiotics and responsible for multiple infections, including bacteremia, pneumonia, meningitis, urinary tract infections, and surgical wounds (Ghajavand et al., 2015). Acinetobacter infections have been historically associated with military and injured soldiers in combat due to direct environmental contamination of wounds (Ecker et al., 2006). In a report described an increasing number of $A$. baumannii bloodstream infections in patients at military medical facilities that were treating service members injured throughout Gulf War and in Afghanistan during Operation Enduring Freedom. This has the potential to become a serious problem in military and veterans' hospitals, where soldiers returning from active duty worldwide are treated in the same environment as other patients (Scott et al., 2004). In the last 20 years, outbreaks caused by carbapenem-resistant $A$. baumannii isolates have become a major worldwide concern (Visca et al., 2011) and infections caused by such pathogen are associated with increased morbidity and mortality (Henig et al., 2015). Due to the high prevalence rate of this infection as well as various patterns of antibiotic resistance in different geographical areas, an investigation on prevalence rate and antibiotic sensitivity pattern in different part of the world is essential (Ghajavand et al., 2015). The ability to gain multiple virulence factors, including resistance determinants such as serum resistance, motility, efflux pumps and iron acquisition mechanisms, in addition to its ability to develop multidrug resistance and to survive in hospital environments for prolonged periods has helped it to emerge as a successful opportunistic nosocomial pathogen (AL-Kadmy et al., 2018). During the past decade, incidence of nosocomial outbreaks by A. baumannii has been described mostly in burn, surgical and intensive care units (Jafari and Karbasizade, 2014). Most surveillance studies report high mortality rates among patients with $A$. baumannii bacteremia and may be associated with considerable morbidity and mortality reach to more than 58\% (Falagas and Rafailidis, 2007; Chuang et al., 2011). Since most outbreaks may a raise from a limited number of clonal lines with specific characteristics, it's essential to develop techniques for rapid identification and characterization of this pathogen and take measures to control the spreading of it among patients. Molecular techniques proved its effectiveness for identification of pathogenic bacteria at species level, detection the virulence genes, and study the genetic relationship of the micooroganisms (Sevillano and Gallego, 2011). The management and prevention spreading of $A$. baumannii in the health care

* Corresponding author

This is an open access under a CC BY-NC-SA 4.0 license (https://creativecommons.org/licenses/by-nc-sa/4.0/) 
settings require to identify potential reservoirs of this organism, the modes of transmission and investigate $A$. baumannii clones cause the outbreaks from epidemiologically unrelated strains, a comparison of isolates at the subspecies level is required by application of molecular typing methods (Sadeghi et al., 2016). This study involved the isolation and identification of $A$. baumannii from sputum specimens, burns and wounds infections of hospitalized patients in Duhok hospitals using conventional and molecular methods, in addition, the investigation of the susceptibility of $A$. baumannii isolates to different antimicrobial agents.

\section{MATERIAL AND METHODS}

\subsection{Sample collection:}

A total of 603 clinical burns and sputum samples were collected during the period from March 2018 to February 2019 at the following hospitals; 226 sputum specimens were collected from patients attending Azadi teaching hospital as well as 111 sputum samples from Duhok Emergency hospital; Moreover, 266 burn infections samples were obtained from patients admitted to Duhok cosmetic and burn hospital. Regarding to the gender, 351 samples have been obtained from female, while 252 were collected from male Table (1).

Table (1): The sample collection from different hospitals from male and female pateints

\begin{tabular}{|l|c|c|}
\hline \multicolumn{1}{|c|}{ Hospital } & Female & Male \\
\hline $\begin{array}{l}\text { Duhok Azadi Teaching Hospital } \\
\text { (ICU) }\end{array}$ & 120 & 106 \\
\hline Emergency Hospital (ICU) & 61 & 50 \\
\hline $\begin{array}{l}\text { Duhok Cosmetic and Burn hospital } \\
\text { (Burned wound) }\end{array}$ & 170 & 96 \\
\hline \multicolumn{1}{|c|}{603} \\
\hline Total & 351 & 252 \\
\hline
\end{tabular}

\subsection{Identification of $A$. baumannii:}

The preliminary conventional phenotypic tests including; growth on MacConkey agar, catalase and oxidase tests, and other standard recommended tests were applied (Forbes et al., 2007; and Golanbar et al., 2011). For definitive phenotypic identification of these isolates, they were cultured on CHROMagar Acinetobacter (CHROMagar, France), MDR $A$. baumannii have been detected after adding MDR supplement (CR102) used for this purpose, in addition to VITEK 2 identification system test using ID-GNB cards, according to the manufacturer's instructions.

\subsection{Antibiotic susceptibility test:}

Seventeen antibiotic disks (Bioanalyse/ Turkey) have been used in this study. Antibiotic sensitivity testing was accomplished by the Kirby-Bauer disc diffusion method. All plates were incubated at $37^{\circ} \mathrm{C}$ for $18 \mathrm{~h}$. After incubation, the diameter of the inhibition zone was measured to the CLSI reference for Acinetobacter spp (CLSI., 2016).

\subsection{Molecular methods:}

The isolates were identified to the genus level using genusspecific PCR assay by 16SrRNA primer as previously described (Ghaima et al., 2016). In brief, a 150 -bp fragment of the 16SrRNA was amplified using pair of primers F $\left(5^{\prime}\right.$ CAGCTCGTGTCGTGAGATGT-3') and R (5'CGTAAGGGCCATGATGACTT-3'). The amplification reaction volume was $25 \mu \mathrm{l}$, and the cycling conditions were as follows: an initial denaturation at $95^{\circ} \mathrm{C}$ for 3 minutes, followed by 30 cycles of denaturation at $95^{\circ} \mathrm{C}$ for 1 minute, annealing at $55^{\circ} \mathrm{C}$ for 1 minute, extension at $72^{\circ} \mathrm{C}$ for 1 minute, and a final extension at $72^{\circ} \mathrm{C}$ for 5 minutes. Species-specific PCR assay with $O X A-51$ gene using $\mathrm{F}$ primer 5'TAATGCTTTGATCGGCCTTG -3 and $\mathrm{R}$ '5 -
TGGATTGCACTTCATCTTGG - $3^{\prime}$ was also applied to confirm the identity of the isolates with expected amplified product 353bp (Ghaima et al., 2016). The amplification reaction volume was $25 \mu \mathrm{l}$, and the cycling conditions were as follows: an initial denaturation at $94^{\circ} \mathrm{C}$ for 5 minutes, followed by 30 cycles at $94^{\circ} \mathrm{C}$ for 40 seconds, $52^{\circ} \mathrm{C}$ for 45 seconds, $72^{\circ} \mathrm{C}$ for 40 seconds and a final extension at $72^{\circ} \mathrm{C}$ for 6 minutes. The amplified products were resolved through electrophoresis and analyzed on $1.5 \%$ agarose gel-stained ethidium bromide.

\subsection{Biostatic analysis:}

Statistical Package for Social Sciences (SPSS) version 22.0 and Microsoft Office Excel were used to analyze the results of the current study. Chi-square test was used and $\mathrm{P}<0.05$ was considered to be statistically significant (Sokal and Rohlf, 2009).

\section{RESULTS AND DISCUSSION}

\subsection{Results}

3.1.1 Strain identification: In this study, 603 clinical samples were collected from different hospitals in Duhok City, Forty one $(6.8 \%)$ of A. baumannii isolates were obtained in total, 19 (3.2\%) were isolated from the sputum samples of inpatients admitted at the intensive care unit and $22(3.64 \%)$ from burn infection (Table 2). Twenty three accounting $63.4 \%$ obtained from females while 15 strains $(36.5 \%)$ were collected from males.

Table 2: Distribution of A. baumannii isolates according to the source and location of isolation

\begin{tabular}{|c|c|c|c|c|c|}
\hline \multicolumn{2}{|c|}{ Location } & Source & $\begin{array}{l}\text { No. of } \\
\text { sample } \\
\text { s }\end{array}$ & $\begin{array}{c}\text { No } \\
\text { Percentag } \\
\text { e of } \\
\text { isolates in } \\
\text { each } \\
\text { hospital }\end{array}$ & $\begin{array}{c}\text { No. of } \\
\text { positiv } \\
e \\
\text { isolates } \\
\%\end{array}$ \\
\hline $\begin{array}{c}\text { Duhok } \\
\text { Azadi } \\
\text { Teaching } \\
\text { Hospital }\end{array}$ & \multirow{2}{*}{ ICU } & $\begin{array}{c}\text { Sputu } \\
\mathrm{m}\end{array}$ & 226 & $13(5.8 \%)$ & $\begin{array}{c}13(2.1 \\
\%)\end{array}$ \\
\hline $\begin{array}{l}\text { Emergenc } \\
\text { y Hospital }\end{array}$ & & $\begin{array}{c}\text { Sputu } \\
\text { m }\end{array}$ & 111 & $6(5.4 \%)$ & $6(1 \%)$ \\
\hline & & & 337 & $19(5.6 \%)$ & $\begin{array}{c}19 \\
(3.2 \%)\end{array}$ \\
\hline $\begin{array}{c}\text { Duhok } \\
\text { Cosmetic } \\
\text { and Burn } \\
\text { hospital }\end{array}$ & $\begin{array}{c}\text { Bur } \\
\text { n } \\
\text { units }\end{array}$ & $\begin{array}{l}\text { Burned } \\
\text { wound }\end{array}$ & 266 & $22(8.3 \%)$ & $\begin{array}{c}22 \\
(3.6 \%)\end{array}$ \\
\hline \multicolumn{3}{|c|}{ Total } & 603 & & $\begin{array}{c}41 \\
(6.8 \%)\end{array}$ \\
\hline
\end{tabular}

Fifty four suspected isolates as $A$. baumannii with late lactose fermenter on MacConkey agar were negative to oxidase test and positive to catalase test appeared on CHROMagar as bright red colonies after $24 \mathrm{hr}$., incubation at $37^{\circ} \mathrm{C}$ (Figure 1-A), this medium is also specific for MDR A. baumannii as it contains MDR Acinetobacter screening supplements.

Although this Chromogenic medium is essential for detection of Acinetobacter and MDR Acinetobacter sp., other bacterial species like Stenotrophomonas maltophilia, Pseudomonas aueroginosa were grown and appeared with similar colonies but smaller size than Acinetobacter, by which they can be distinguished from each other (Figure 1-B). Indeed, further confirmatory tests were required. In this regard, VITEK 2 
Identification System test using ID-GNB cards was utilized according to the manufacturer's instructions. Out of 54 suspected isolates, only 41 isolates were confirmed as Acinetobacter while other 13 isolates stood for other bacteria, 3 isolates were identified as A. ursingii, 3 as Stenotrophomonas

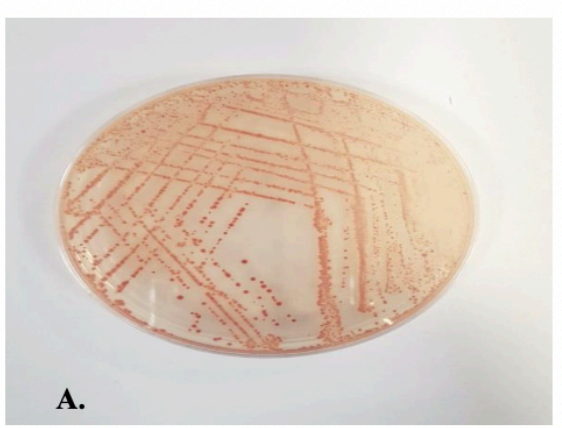

maltophilia and 7 samples were identified as Pseudomonas aueroginosa. Thus, the sensitivity of CHROMagar result was $75.9 \%$. While VITEK 2 Identification System test showed $100 \%$ accuracy after comparison with molecular methods.

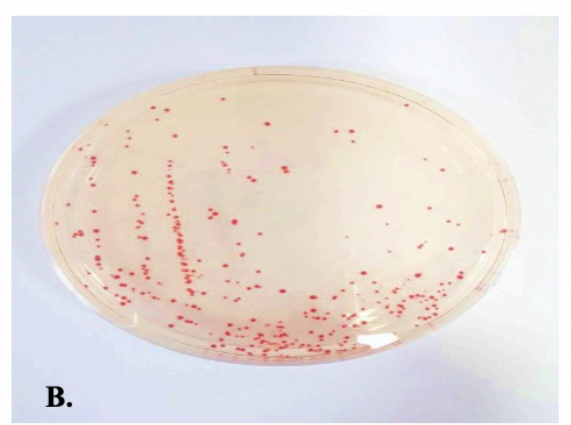

Figure 1-A: Colonies of Acinetobacter baumannii, B. colonies of Stenotrophomonas maltophilia after $24 \mathrm{hrs}$. of incubation at $37^{\circ} \mathrm{C}$ on CHROMagar Acinetobacter.

3.1.2 Antibiotic Susceptibility Test: The results of antimicrobial susceptibility test showed that the forty one $A$. baumannii isolates varied in their sensitivity toward antibiotics used in this study. Ten categories of antimicrobial agents have been used in this study as shown in Table (2). It is worth mentioning, only $10(24.4 \%)$ isolates were appeared to be resistant to a minimum of 3 classes of selected antibiotics, in other words, MDR A. baumannii. While 27 isolates accounting $65.9 \%$ were susceptible to two or fewer of antimicrobial categories, considered as XDR A. baumannii strains. None of these isolates showed its resistancy against all classes of antimicrobial agents. Colistin was the only antimicrobial agent that has potent effects on all 41 isolates with $100 \%$ sensitivity rate. In other hand, all isolates were resistant $(100 \%)$ to cefixime, cefotaxime, ceftriaxone, ceftazidime, piperacilin-tazobactam, amoxicillin-tazobactam, with high resistance rate to ciprofloxacin, norfloxacin and trimethoprim-Sulfamethoxazole with resistant rate $98 \%, 98 \%$ and 95\%, Respectively. Gentamycin, meropenem and amikacin showed low efficacy of these isolates with resistant rate $93 \%, 93 \%$ and $90 \%$, orderly. Azythromycin and imipenem have high resistance rate $83 \%$. Levofloxacin has a moderate effect on these isolates $51 \%$, followed by doxycyclin $39 \%$.

Table 2: Antimicrobial Susceptibility test Results of 41 Acinetobacter baumannii isolates

\begin{tabular}{|c|c|c|c|c|c|c|}
\hline No & Name & Code & $\begin{array}{l}\text { No. of susceptible } \\
\text { isolates of } A . \\
\text { baumannii }\end{array}$ & Sensitivity $\%$ & $\begin{array}{l}\text { No. of resistant } \\
\text { isolates of } A . \\
\text { baumannii }\end{array}$ & Resistancy \% \\
\hline & \multicolumn{6}{|c|}{ Amino glycoside } \\
\hline 1 & Amikacin & $\mathrm{AK}$ & 4 & $10 \%$ & 37 & $90 \%$ \\
\hline \multirow[t]{2}{*}{2} & Gentamycin & $\mathrm{CN}$ & 3 & $7 \%$ & 38 & $93 \%$ \\
\hline & \multicolumn{6}{|c|}{ Cephalosporins } \\
\hline 3 & Cefixime & CFM & 0 & $0 \%$ & 41 & $100 \%$ \\
\hline 4 & Cefotaxime & CTX & 0 & $0 \%$ & 41 & $100 \%$ \\
\hline 5 & Ceftriaxone & CRO & 0 & $0 \%$ & 41 & $100 \%$ \\
\hline \multirow[t]{2}{*}{6} & Ceftazidime & CAZ & 0 & $0 \%$ & 41 & $100 \%$ \\
\hline & \multicolumn{6}{|c|}{ Quinolones } \\
\hline 7 & Ciprofloxacin & CIP & 1 & $2 \%$ & 40 & $98 \%$ \\
\hline 8 & Levofloxacin & LIV & 20 & $49 \%$ & 21 & $51 \%$ \\
\hline \multirow[t]{2}{*}{9} & Norfloxacin & NOR & 1 & $2 \%$ & 40 & $98 \%$ \\
\hline & \multicolumn{6}{|c|}{ Tetracycline } \\
\hline \multirow[t]{2}{*}{10} & Doxycyclin & DO & 25 & $61 \%$ & 16 & $39 \%$ \\
\hline & \multicolumn{6}{|c|}{ Penicillin } \\
\hline \multirow[t]{2}{*}{11} & $\begin{array}{l}\text { Piperacilin- } \\
\text { Tazobactam }\end{array}$ & PRL & 0 & $0 \%$ & 41 & $100 \%$ \\
\hline & \multicolumn{6}{|c|}{ Trimethoprim } \\
\hline \multirow[t]{2}{*}{12} & $\begin{array}{c}\text { Trimethoprim- } \\
\text { Sulfamethoxazole }\end{array}$ & SXT & 2 & $5 \%$ & 39 & $95 \%$ \\
\hline & \multicolumn{6}{|c|}{ Macrolides } \\
\hline \multirow[t]{2}{*}{13} & Azythromycin & AZM & 7 & $17 \%$ & 34 & $83 \%$ \\
\hline & \multicolumn{6}{|c|}{ lactam/lactamase Inhibitor } \\
\hline
\end{tabular}




\begin{tabular}{|c|c|c|c|c|c|c|}
\hline 14 & $\begin{array}{l}\text { Amoxicillin- } \\
\text { Tazobactam }\end{array}$ & $\mathrm{AMC}$ & 0 & $0 \%$ & 41 & $100 \%$ \\
\hline & \multicolumn{6}{|c|}{ Carbapenems } \\
\hline 15 & Imipenem & IPM & 9 & $22 \%$ & 32 & $88 \%$ \\
\hline \multirow[t]{2}{*}{16} & Meropenem & MEM & 3 & $7 \%$ & 38 & $93 \%$ \\
\hline & \multicolumn{6}{|c|}{ Polymyxin } \\
\hline 17 & Colistin & CT & 41 & $100 \%$ & 0 & $0 \%$ \\
\hline
\end{tabular}

3.1.3 Detection of $A$. baumannii at molecular level: All isolates were identified as Acinetobacter spp. at molecular level using 16SrRNA region, 41 isolates successfully produced amplicon with 150-bp corresponding to the target region (Figure 2). Moreover, these isolates were subjected to molecular confirmation as Acinetobacter baumannii using primer for detection $b a_{\text {OXA-51 }}$ gene with 353-bp amplicon size. The results of PCR showed that this gene exists in all 41 isolates which had been identified as A. baumannii (Figure 3).

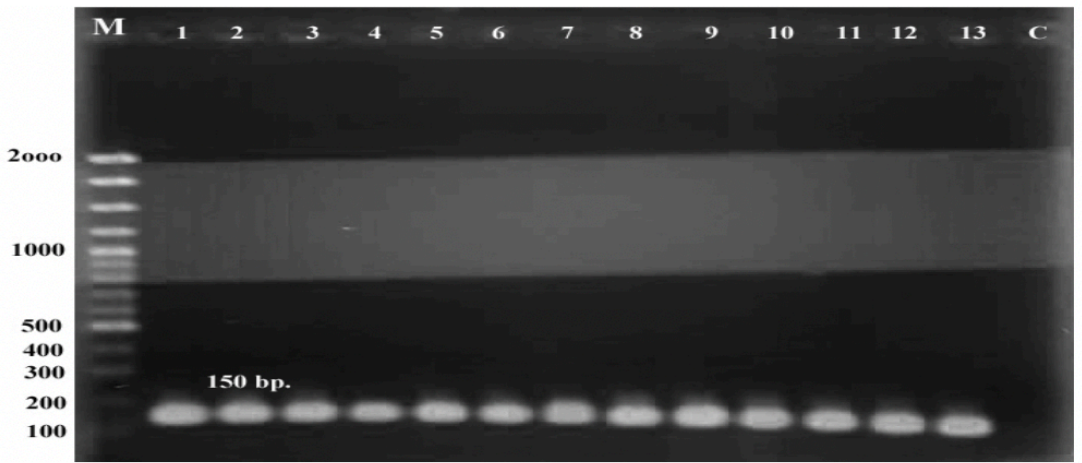

Figure 2. The PCR results of 16S rRNA gene of A. baumannii isolates. Lane (M): Molecular marker (2000bp ladder), Lane (1-13): show positive results with positive bands of 150 -bp, lane (C): Negative control. Electrophoresis was performed on $1.5 \%$ agarose gel run with $5 \mathrm{~V} / \mathrm{CM}$.

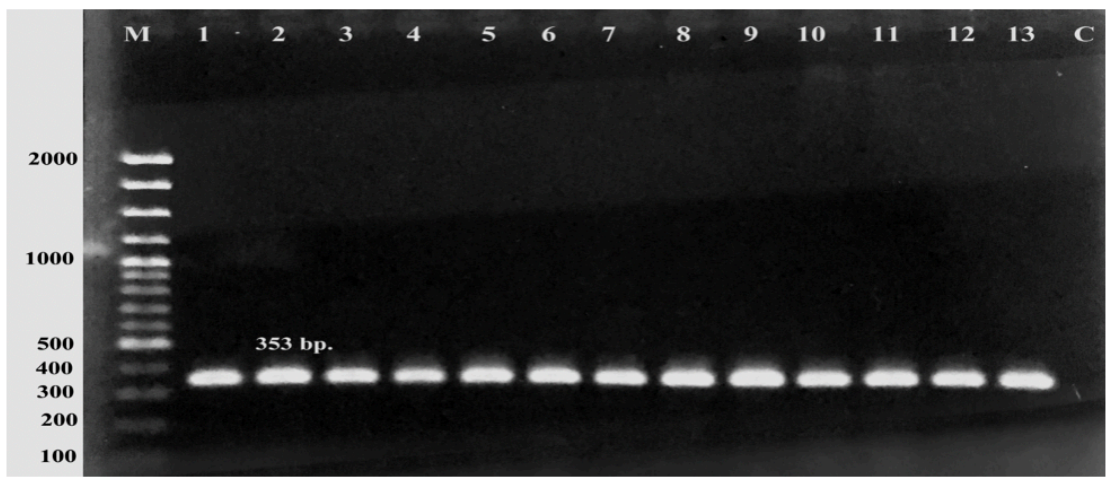

Figure 3. The PCR results of OXA-51 gene of A. baumannii isolates. Lane (M): Molecular marker (2000bp ladder), Lane (1-13): show positive results with positive bands of 353-bp OXA-51 gene of A. baumannii, lane (14): Negative control. Electrophoresis was performed on $1.5 \%$ agarose gel ran with $5 \mathrm{~V} / \mathrm{CM}$.

\section{CONCLUSION}

The emergence of MDR A. baumannii strains at health care institutions in our region as well as globally require more surveillance concern on the molecular characterization and the epidemiology of A. baumannii strains enrolled in our region.

\section{REFERENCES}

Asadollahi P, Akbari M, Soroush S, Taherikalani M, Asadollahi K, Sayehmiri K, Maleki A, Maleki MH, Karimi P, Emaneini M. (2012) Antimicrobial resistance patterns and their encoding genes among Acinetobacter baumannii strains isolated from burned patients. Burns; 38(8):1198-203.

AL-Kadmy I.M.S. , Ali A.N.M., Salman I.M.A. , and Khazaal S.S. (2018). Molecular characterization of Acinetobacter baumannii isolated from Iraqi hospital environment. New Microbes New Infect. 21: 51-57.
AL-Masoudi Khitam K., AL-Saffar Jinan M., Kendla Nuha J. (2015) Molecular Characteristics of Multidrug Resistant Acinetobacter baumannii Isolated from Baghdad Hospitals. Iraqi Journal of Science, 1 56(2B): 1394-1399.

Al-Tamimi Mohammad, Hijamwi Kamal and Harvey Heather Lee(2017) Incidence and characterization of multidrug resistance Acinetobacter baumannii, 3rd World Congress and Exhibition on Antibiotics and Antibiotic Resistance, J Drug Metab Toxicol, 8:2(Suppl.(

Amudhan MS, Sekar U, Kamalanathan A, Balaraman S. (2012.) blaIMP and blaVIM mediated carbapenem resistance in Pseudomonas and Acinetobacter species in India. J Infect Dev Ctries 6:757-762.

Antunes, L. C., Visca, P., and Towner, K. J. (2014) Acinetobacter baumannii: evolution of a global pathogen. Pathogens and Disease, 71(3) 292-30.

Babaie Z, Delfani S, Rezaei F, Norolahi F, Mahdian S, Shakib P.(2019). Molecular Detection of Carbapenem Resistance in Acinetobacter baumannii Isolated 
From Patients in Khorramabad City, Iran. Infect Disord Drug Targets.

Balaky Salah Tofik Jalal, Abdulkhalik Haval, Hussen Bashdar M., Hassan Hozan, Mawlood Ahang Hasan(2019). Molecular Identification of Acinetobacter baumanii and Acinetobacter genomic species 13TU Using PCR, Zanco Journal of Pure and Applied Sciences, 31 (1); 17-22.

Banerjee Tuhina, Mishra Anwita, Das Arghya, Sharma Swati, Barman Hiranmay, and Yadav Ghanshyam (2018). High Prevalence and Endemicity of Multidrug Resistant Acinetobacter spp. in Intensive Care Unit of a Tertiary Care Hospital, Varanasi, India, Journal of Pathogens, Vol. 2018, pp. 1-8

Bergen, P. J., Landersdorfer, C. B., Zhang, Zhao, M., Lee, H. J., Nation, R. L., and Li, J. (2012). Pharmacokinetics and pharmacodynamics of 'old' polymyxins: what is new? Diagnostic Microbiology and Infectious Disease, 74(3), 213223.

Cai, Y., Chai, D., Wang, R., Liang, B., and Bai, N. (2012). Colistin resistance of Acinetobacter baumannii: clinical reports, mechanisms and antimicrobial strategies. The Journal of Antimicrobial Chemotherapy, 67(7), 1607-1615.

Chim H, Tan BH, Song C.(2007) Five-year review of infections in a burn intensive care unit: High incidence of Acinetobacter baumannii in a tropical climate. Burns. 33 (8): 1008-14.

Ciftci A. Y.., Karakeca E.,Atasoy A. R., Asik G., Ciftci I H. (2015)Culture media for detection of Acinetobacter baumannii selective media for detection of Acinetobacter baumannii; Journal of microbiology and expermintation, Vol. 2, Issue (5.)

Chuang YC, Sheng WH, Li SY, Lin YC, Wang JT, Chen YC, Chang SC. (2011)Influence of genospecies of Acinetobacter baumannii complex on clinical outcomes of patients with Acinetobacter bacteremia. Clin Infect Dis.; 52: 352-360. Clinical and Laboratory Standards Institute (2016) Performance Standards for Antimicrobial Susceptibility Testing: Nineteenth Informational Supplement M100-S19. Wayne, USA: CLSI. 26th ed. Pp. 66

Coskun Umut Safiye Say, Caliskan Emel, Cicek A. C.; Turumtay H. and Sandalli Cemal (2019) lactamase genes in carbapenem resistance Acinetobacter baumannii isolates from a Turkish university hospital, J Infect Dev Ctries; 13(1):50-55.

Ecker J. A., Massire C., Hall T. A., Ranken R., . Pennella T. T., Agasino Ivy C, Blyn LB, Hofstadler SA, Endy TP, Scott PT, Lindler L, Hamilton T, Gaddy C, Snow K, Pe M, Fishbain J, Craft D, Deye G, Riddell S, Milstrey E, Petruccelli B, Brisse S, Harpin V, Schink A, Ecker DJ, Sampath R, Eshoo MW., (2006) Identification of Acinetobacter Species and Genotyping of Acinetobacter baumannii by Multilocus PCR and Mass Spectrometry, Journal Of Clinical Microbiology, 44( 8): 2921-2932.Evans B. A. and Amyesb S. G. B. (2014) OXA -Lactamases. Clin Microbiol Rev; 27(2): 241-263.Falagas ME, Rafailidis PI. (2007) Attributable mortality of Acinetobacter baumannii: no longer a controversial issue. Crit Care; 11: 134 .

Forbes BA, Sahm DF, Weissfeld AS. (2007) Bailey \& Scott's diagnostic microbiology. 12th ed. St Louis, MO: Mosby.
Ganjo AR, Maghdid DM, Mansoor IY, Kok DJ, Severin JA, Verbrugh HA, Kreft D, Fatah MH, Alnakshabandi AA, Dlnya A, Hammerum AM, Ng K, Goessens W. (2016).OXA-Carbapenemases Present in Clinical Acinetobacter baumannii-calcoaceticus Complex Isolates from Patients in Kurdistan Region, Iraq. Microb Drug Resist. 22(8):627-637.

Ghaima K. K., Saadedin MK. SH. And JassimA. K. (2016). Isolation, molecular identification and antimicrobial susceptibility of Acinetobacter baumannii isolated from Baghdad hospitals. International Journal of Scientific and Research Publications, 6 (5): 352

Ghajavand H. , Esfahani B. N. , Havaei S. A. , Moghim S. , and Fazeli H. (2015). Molecular identification of Acinetobacter baumannii isolated from intensive care units and their antimicrobial resistance patterns. Adv Biomed Res. 4: 110.

Giannouli M, Cuccurullo S, Crivaro V, Popolo A, Brnarardo M, Tomasone F, Amato G, Brisse S, Triassi M, Utili R, Zarrilli R.. (2010). Molecular Epidemiology of Multidrug-Resistant Acinetobacter baumannii in a Tertiary Care Hospital in Naples, Italy, Shows the Emergence of a Novel Epidemic Clone. J Clin Microbiol. 48: 1223-1230.

Golanbar G. D. , Lam CK, Chu Y. M., Cueva C, Tan S. W., Silva I., and $\mathrm{Xu}$ HH.. (2011) Phenotypic and molecular characterization of Acinetobacter clinical isolates obtained from inmates of California correctional facilities. J Clin Microbiol;49:2121e31.

Gordon NC, Wareham DW. (2009) Evaluation of CHROMagar Acinetobacter for Detection of Enteric Carriage of Multidrug-Resistant Acinetobacter baumannii in Samples from Critically Ill Patients. Journal of Clinical Microbiology. 47: 2249 -2251.

Henig O, Weber G, Hoshen MB, Paul M, German L, Neuberger A Gluzman I, Berlin A, Shapira C, Balicer RD. (2015) Risk factors for and impact of carbapenem-resistant Acinetobacter baumannii colonization and infection: matched case-control study. Eur J Clin Microbiol Infect Dis. 34: 2063-8.

Howard A, O’Donoghue M, Feeney A, Sleator RD. (2012) Acinetobacter baumannii. Clin Microbiol Rev. $3: 243-250$.

Ibrahim Mutasim E. ( 2019) Prevalence of Acinetobacter baumannii in Saudi Arabia: risk factors, antimicrobial resistance patterns and mechanisms of carbapenem resistance. Ann Clin Microbiol Antimicrob, 18: 1.

Jafari R, Karbasizade V. (2014). Frequency and Antimicrobial Susceptibility of Acinetobacter baumannii in Burn infections in Isfahan, Iran. Advances in Bioresearch; 5 (2): 148-152 .

Murray CK, Hospenthal DR. (2008) Acinetobacter infection in the ICU. Crit Care Clin. 24: 237-248.

Nageeb W., Kamel M., Zakaria S., Metwally L (2014) Phenotypic characterization of Acinetobacter baumannii isolates from intensive care units at a tertiary-care hospital in Egypt. East Mediterr Health J. 3;20(3):203-11.

Ni HB, Zhang Z, Qin HD. (2011) Protective effect of glutamine in critical patients with acute liver injury. World J Emerg Med; 2: 210-215.Sadeghi Parisa, Khosravi Azar Dokht, Shahraki Abdolrazagh Hashemi, and BeiranvMaryam (2016) Identification of clinical isolates of Acinetobacter baumannii from Iran and study of 
their heterogeneity. Journal of the Chinese Medical Association 79, 382e386.

Scott, P. T., K. Petersen, J. Fishbain, D. W. Craft, A. J. Ewell, K. Moran, D. C. Hack, G. A. Deye, S. Riddell, G. Christopher, J. D. Mancuso, B. P. Petruccelli, T. Endy, L. Lindler, K. Davis, E. G. Milstrey, L. Brosch, J. Pool, C. L. Blankenship, C. J. Witt, J. L. Malone, D. N. Tornberg, A. Srinivasan, and the Centers for Disease Control and Prevention. (2004). Acinetobacter baumannii infections among patients at military medical facilities treating injured U.S. service members, 2002-2004. Morbid. Mortal. Wkly. Rep. 53: 1063-1066.

Sevillano E. and Gallego (2011) Molecular techniques for detection and control of nosocomial infections caused by Acinetobacter baumannii. Science against microbial pathogens: communicating current research and technological advances, 495503.

Shali A. (2012). Identification of multidrug - resistant genes in Acinetobacter baumannii in Sulaimani city Kurdistan regional government of Iraq. Asian Journal of Medical Sciences; 4(5): 179-183 .

Turton JF, Woodford N, Glover J, Yarde S, Kaufmann ME, Pitt TL.(2006) Identification of Acinetobacter baumannii by detection of the blaOXA-51-like carbapenemase gene intrinsic to this species. J Clin Microbiol.;44(8):2974-6.
Turton JF, Ward ME, Woodford N, Kaufmann ME, Pike R, Livermore DM, Pitt TL. (2006b). The role of ISAbal in expression of OXA carbapenemase genes in Acinetobacter baumannii. FEMS Microbiol Lett. 258(1):72-7.

Valencia, R., Arroyo, L. A., Conde, M., Torres M. J, Fernández-Cuenca F, Garnacho-Montero J, Cisneros JM, Ortíz C, Pachón J, Aznar J. (2009). Nosocomial outbreak of infection with pan-drug resistant Acinetobacter baumannii in a tertiary care university hospital. Infection Control and Hospital Epidemiology, 30(3), 257-263.

Visca P, Seifert H, Towner KJ. (2011) Acinetobacter infection-an emerging threat to human health. IUBMB Life; 63: $1048-54$

Zarrilli R, Giannouli M, Tomasone F, Triassi M, Tsakris A. (2009) Carbapenem resistance in Acinetobacter baumannii: the molecular epidemic features of an emerging problem in health care facilities. J Infect Dev Ctries. 3: 335-341.

Zeka AN, Poirel L, Sipahi OR, Bonnin RA, Arda B, Ozinel M, Ulusoy S, Bor C, Nordmann P. (2014) GES-type and OXA-23 carbapenemase-producing Acinetobacter baumannii in Turkey. J Antimicrob Chemother ;69(4):1145-6. 